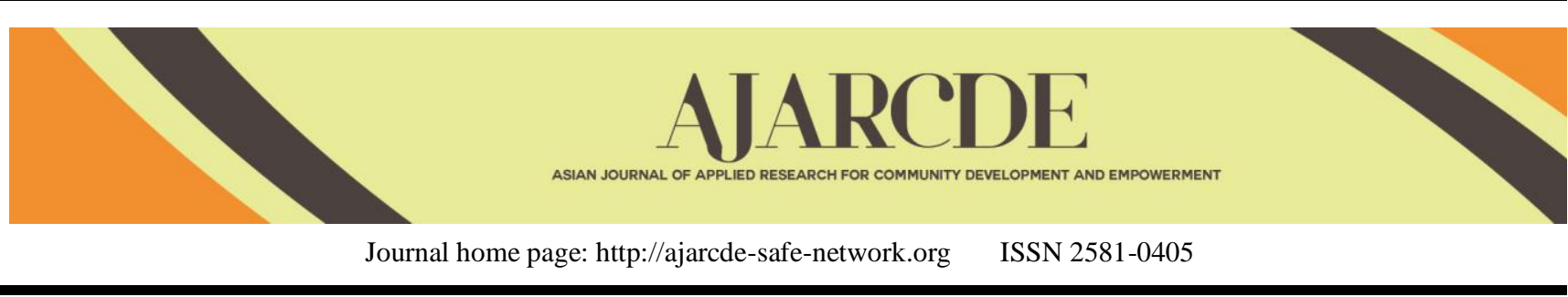

\title{
Lethality Test of Some Varieties of Sea Cucumber Extract Against Artemia Salina, as Natural Food Additive in Meat-Based Functional Food
}

\author{
Djoko Kisworo, Sukirno, Bulkaini \\ Animal Products Processing Technology, University of Mataram, Jl. Majapahit 62 Mataram, Indonesia
}

\section{ARTICLE INFO}

Article History:

Received: 11 August 2021

Final Revision: 30 August 2021

Accepted: 2 October 2021

Online Publication: 10 October 2021

\section{KEYWORDS}

Beef Meatballs, Total Bacteria, Sea Cucumber, BSLT.

\section{CORRESPONDING AUTHOR}

*E-mail: djokokisworo@unram.ac.id

\section{A $\quad$ B $\quad \mathbf{S}$ T $\mathbf{R}$ A $\mathbf{C}$ T}

\section{INTRODUCTION}

\subsection{Research Background}

Cancer is the leading cause of death in developed countries and the second leading cause of death in developing countries. In 2008 there were 12.7 million cancer patients worldwide (56\% of whom were in developing countries) and resulted in the death of 7.6 million people (64\% in developing countries) [1]. The prevalence of cancer sufferers in Indonesia reaches 4.3 people per 1,000 population. With a population of 237.6 million in 2010 , cancer sufferers in Indonesia are estimated at 1.02 million [2].

Various ways to prevent cancer that can be done include primary, secondary, and tertiary prevention, in which diet and type of food regulation are types of primary prevention. Cancer treatment can be done by, among others, surgery, chemotherapy, radiation, immunotherapy, and gene therapy. In recent decades, the concept of functional foods has offered new and practical approaches to achieving optimal health by promoting the use of natural products with physiological benefits thereby reducing the risk of various chronic diseases. Most of the functional foods that are therapeutic agents come from natural sources, especially, terrestrial food plants and marine species. Due to the rich marine biodiversity, marine organisms are a source of nutritious food, a source of active biological components, especially bioactive peptides, as well as antimicrobial agents, anti-inflammatory and anticancer agents, one of which is a sea cucumber.

Given the medical and health benefits, sea cucumbers have the potential bioactive peptides as a natural food preservative to be introduced into meat-based foods that are very popular in the community such as meatballs, sausages, and corned beef so that they become functional foods that can prevent and treat cancer.

\subsection{Literature Review}

Sea cucumbers are marine invertebrates that have a body shape like cucumber which are members of echinoderms, commonly known as teripang, or gamat, have long been utilized in the food and folk medicine systems of Asia and Middle East communities [3] and [4], which has important economic value because it contains high nutrients and is empirically believed to be a food ingredient has properties as a medicinal ingredient (Nutraceutical) [5]. According to Ref. [6], the health benefits obtained after consuming sea cucumbers are vitality, because sea cucumbers contain bioactive compounds including terpenoids, 
saponins, essential amino acids, glycosaminoglycans, chondroitin sulfates, sulfate polysaccharides, sterols, lectins, phenols, and peptides.

\subsection{Research Objective}

The research aimed to examine the lethality of some varieties of sea cucumber against artemia salina, as a natural food additive in meat-based functional food, and the organoleptic value of meatball as added with sea cucumber powder.

\section{MATERIALS AND METHODS}

\subsection{Materials}

The basic material used in this research were five varieties of sea cucumber (Holothuria Sp) purchased by the fishermen of the crew of the village at Kuta-Lombok Island and Bungin Island, The ingredients used to make the meatballs were beef thigh purchased at the Kebon Roek market, STPP, tapioca flour, ice cubes, garlic, fried shallots, salt, and pepper. While the materials for the total bacterial count were: meatball samples, NA (nutrient agar), distilled water, $70 \%$ alcohol, aluminum foil, sterile physiological $\mathrm{NaCl}$, and label paper.

\subsection{Research methods}

\subsubsection{Sea Cucumber Extraction}

Dry samples of five varieties of sea cucumbers were weighed including Holothuria similis (127.95 grams), Pearsonothuria graeffei (121.00 grams), Thelenota anax (183.00 grams), Holothuria fuscogilva (161.00 grams), and Bohadschia marmorata (225, 00 grams) and each variety was extracted by ordinary maceration. The dried samples of sea cucumbers were cut into small pieces and 100 to $200 \mathrm{ml}$ of methanol from the soaking samples were added to the blender [7] and [8]. Once smooth, the sample was put into a $1000 \mathrm{ml}$ beaker glass and then macerated with methanol for 24 hours. The obtained filtrate was then filtered using Whatman filter paper no.1. The filtrate obtained was put into the evaporating flask, then evaporated using a vacuum rotary evaporator at a temperature of $40{ }^{\circ} \mathrm{C}$ at $90 \mathrm{rpm}$ so that it thickens into a crude extract. After that, the crude extract was weighed and stored in a dark bottle.

\subsubsection{Test for the lethality of the active compounds of sea cucumber extract [9]}

The concentration of sea cucumber extract solution was made as follows. As much as $0.5 \mathrm{~g}$ of each crude extract from 5 varieties of sea cucumbers, namely Holothuria similis, Pearsonothuria graeffei, Thelenota anax, Holothuria fuscogilva, and Bohadschia marmorata, were diluted using methanol up to $50 \mathrm{ml}$. The solution obtained from each type was called the mother liquor with a concentration value of $10,000 \mu \mathrm{g} / \mathrm{ml}$, then each mother liquor was diluted to several final concentrations in vials, namely $1000 \mu \mathrm{g} / \mathrm{ml}, 750 \mu \mathrm{g} / \mathrm{ml}, 500 \mu \mathrm{g} / \mathrm{ml}, 250 \mu \mathrm{g} / \mathrm{ml}, 100 \mu \mathrm{g} / \mathrm{ml}$, $75 \mu \mathrm{g} / \mathrm{ml}, 50 \mu \mathrm{g} / \mathrm{ml}, 25 \mu \mathrm{g} / \mathrm{ml}$, and $10 \mu \mathrm{g} / \mathrm{ml}$. Furthermore, as much as $0.5 \mathrm{ml}$ of each concentration was put into a vial bottle and as a control, a vial was provided which contained methanol with the same volume of $0.5 \mathrm{ml}$. One concentration series was carried out three times (triple). All crude extract and control solutions in the vial bottles were allowed to dry at room temperature for approximately 24 hours.

\subsubsection{Hatching Artemia salina eggs [9]}

Artemia salina eggs (0.2 g / $1000 \mathrm{ml}$ seawater) were placed in a container (aquarium) filled with seawater. During hatching, seawater was given an aerator to circulate air in the aquarium. The eggs start hatching after 24 hours. The eggs hatch and move actively at the age of 36 to 48 hours. The 48-hour age of Artemia known as Artemia salina nauplii was used in the BSLT test.

\subsubsection{Brine Shrimp Lethality Test (BSLT) [9]}

A total of 10 Artemia salina nauplii were piped into each vial bottle containing crude extract with various concentrations and controls, then added seawater until the final volume was $5 \mathrm{ml}$. The final concentrations in the vial after the addition of seawater are $1000 \mu \mathrm{g} / \mathrm{ml}, 750 \mu \mathrm{g} / \mathrm{ml}, 500 \mu \mathrm{g} / \mathrm{ml}, 250 \mu \mathrm{g} / \mathrm{ml}, 100 \mu \mathrm{g}$ / $\mathrm{ml}, 75 \mu \mathrm{g} / \mathrm{ml}, 50 \mu \mathrm{g} / \mathrm{ml}, 25 \mu \mathrm{g} / \mathrm{ml}$, and $10 \mu \mathrm{g} / \mathrm{ml}$. Then the vial was closed with a rubber cap and left for 24 hours. Deaths at each concentration were recorded and compared with controls, then calculated using the formula:

$$
\% \text { Lethality }=\text { - } \frac{\sum \text { Mortality of every Concentration }-\sum \text { Mortality of Control }}{\sum \text { Early Larvae }}
$$

Calculation of LC50 was done using Ms. Excel. An extract is said to be active if the obtained LC50 value $=1000 \mu \mathrm{g} / \mathrm{ml}$.

\subsubsection{Meat-based food (meatballs processing)}

According to Ref. [10] and [11], the working steps of processing meatballs were as follows: 1 . Fresh beef cut into small pieces and then ground together with all other ingredients (ice, salt, STPP, tapioca flour, sea cucumber extract, garlic, fried shallots, and pepper; 2 . Let the dough stand for 30 minutes in the refrigerator; 3 . The dough was formed into a round shape and then boiled at a temperature of $65^{\circ} \mathrm{C}$ until it arises on the surface, then boiled until cooked at a temperature of $100^{\circ} \mathrm{C}$.

\begin{tabular}{|llll|}
\multicolumn{5}{c}{ Table 1. Meatballs Formula } \\
\hline \multirow{3}{*}{ INGREDIENT } & $1^{\text {st }}$ & $2^{\text {nd }}$ & $3^{\text {rd }}$ \\
& Formula & Formula & Formula \\
\cline { 2 - 4 } & $\%$ & $\%$ & $\%$ \\
\hline Sea cucumber flour & 0 & 2 & 4 \\
Fresh beef & 54 & 52 & 50 \\
Tapioca flour & 20 & 20 & 20 \\
Salt & 1.5 & 1.5 & 1.5 \\
Garlic & 2 & 2 & 2 \\
Fried shallots & 1.5 & 1.5 & 1.5 \\
Pepper & 0.5 & 0.5 & 0.5 \\
STPP & 0.5 & 0.5 & 0.5 \\
Ice Cube & 20 & 20 & 20 \\
\hline Total & 100 & 100 & 100 \\
\hline
\end{tabular}

\subsection{Data analysis}

\subsubsection{Observed variables}

The variables observed in this study were the proliferation of cancer cells in various treatments and total bacteria in meatballs as the main variable and visual observation of meatballs as supporting variables.

\subsubsection{Total bacterial count procedure}

Total bacteria count in beef meatball samples using the TPC (Total Plate Count) method [12]. To report the results of the https://doi.org/10.29165/ajarcde.v5i3.73 
microbiological analysis as Standard Plate Count (SPC), the following procedure was carried out [13]:

1) The number of colonies that meet the counting requirements is between 25 and 250 .

2) Several colonies that are joined into one large colony, can be counted as one colony.

3) A row of colonies that is visible as one solid line can be counted as one colony.

\section{RESULT AND DISCUSSION}

\subsection{Lethality test}

The BSLT test results for the five types of sea cucumbers are listed in the following table, the extracts of the five types of dried sea cucumbers were tested at various concentrations, ranging from $10 \mu \mathrm{g} / \mathrm{mL}$ to $1000 \mu \mathrm{g} / \mathrm{mL}$.

Table 2. BSLT (Artemia salina) test results

\begin{tabular}{|c|c|c|c|}
\hline No. & $\begin{array}{l}\text { Varieties of Sea } \\
\text { Cucumber }\end{array}$ & $\begin{array}{l}\text { Average of } \\
\text { Deaths (\%) }\end{array}$ & $\begin{array}{l}\text { Lethal } \\
\text { Concentration } \\
(\mu \mathrm{g} / \mathrm{Ml})\end{array}$ \\
\hline 1 & $\begin{array}{l}\text { Holothuria } \\
\text { similis }\end{array}$ & 56.30 & 25.00 \\
\hline 2 & $\begin{array}{l}\text { Pearsonothuria } \\
\text { graeffei }\end{array}$ & 48.89 & 70.31 \\
\hline 3 & Thelenota anax & 26.67 & 937.50 \\
\hline 4 & $\begin{array}{l}\text { Holothuria } \\
\text { fuscogilva }\end{array}$ & 32.59 & 661.76 \\
\hline 5 & $\begin{array}{l}\text { Bohadschia } \\
\text { marmorata }\end{array}$ & 48.52 & 357.14 \\
\hline
\end{tabular}

The results of the analysis of the BSLT test with the help of Ms. Excel show that the LC50 value of crude extract from the five types of sea cucumbers studied varies as shown in Table 2. Of the five types of sea cucumber, Holothuria similis produced the most active crude extract $(25.00 \mu \mathrm{g} / \mathrm{ml})$, while Thelenota anax produced the crude extract with the lowest activity namely 937.50 $\mu \mathrm{g} / \mathrm{ml}$. This means that the crude extract of the five types of sea cucumbers was active against BSLT because the resulting LC50 value was less than $1000 \mu \mathrm{g} / \mathrm{ml}$ [14]. Two of the five types of sea cucumbers (Holothuria similis and Pearsonothuria graeffei) have a crude extract activeness value which can be said to be very active because it ranges from the standard value of activeness from the American National Cancer Institute (NCI) which states the standard for the effectiveness of bioactive components to fight cancer cells is $=30 \mu \mathrm{g} / \mathrm{ml}$.

\subsection{Total Bacteria Count of Beef Meatball}

The results of the total bacteria count of beef meatball given the addition of sea cucumber extract at various levels can be seen in Table 4. It can be seen that the folded extract can effectively reduce the bacterial content of meatballs during the storage period.

Based on the observations, it was evident that the higher the level of sea cucumber extract, the lower the content of the meatball bacteria. If it is related to the effectiveness of the extract against the inhibition of cancer cells, it turns out that the heating treatment (autoclave in the extraction and heating in the meatball ripening process) strengthens the killing power of both cancer cells and bacterial cells. Meanwhile, for the second day of storage, the total bacterial colonies continued to show an increase, this was more due to contamination during room temperature storage without packaging.

Table 4. Total bacteria count of meatball in various treatments (Log CFU mL ${ }^{-1}$ )

\begin{tabular}{|llll|}
\hline \multirow{2}{*}{$\begin{array}{l}\text { Sea Cucumber } \\
\text { Flour }(\%)\end{array}$} & \multicolumn{3}{l}{ Storage Period (day) } \\
\cline { 2 - 4 } & 0 & 1 & 2 \\
\hline 0 (Control) & 3.11 & 5.42 & 8.07 \\
2 & 2.95 & 5.42 & 7.89 \\
4 & 2.75 & 5.36 & 7.89 \\
\hline Average & 2.94 & 5.40 & 7.96 \\
\hline
\end{tabular}

Ref. [12], stated that anti-bacterial work is influenced by several things, namely antibacterial concentration, bacterial species, number of bacteria, environmental $\mathrm{pH}$, and including temperature. During the observation, no fungus grew. This shows that teripang extract can inhibit fungal growth during storage.

\subsection{Visual Observation of Beef Meatballs}

Physical observations of beef meatballs with the addition of sea cucumber extract can be seen in Table 5. Physical observations include smell, texture, and formation of mucus during storage at room temperature $\left(28{ }^{\circ} \mathrm{C}\right)$.

Table 5. Visual observation results of meatballs with added sea cucumber flour

\begin{tabular}{|c|c|c|c|}
\hline \multirow{2}{*}{$\begin{array}{l}\text { TREATMENTS } \\
(\%)\end{array}$} & \multicolumn{3}{|c|}{ Storage Period (day) } \\
\hline & 0 & 1 & 2 \\
\hline \multicolumn{4}{|l|}{$0 \%$ (Control) } \\
\hline Aroma & Normal & $\begin{array}{l}\text { Appear Acid } \\
\text { Smell }\end{array}$ & Rotten Odor \\
\hline Texture & Chewy & $\begin{array}{l}\text { Start to } \\
\text { Softened }\end{array}$ & $\begin{array}{l}\text { Crumbling } \\
\text { Easily }\end{array}$ \\
\hline Mucus & - & + & ++ \\
\hline \multicolumn{4}{|l|}{$2 \%$} \\
\hline Aroma & Normal & $\begin{array}{l}\text { Appear Acid } \\
\text { Smell }\end{array}$ & Rotten Odor \\
\hline Texture & Chewy & $\begin{array}{l}\text { Start to } \\
\text { Softened }\end{array}$ & $\begin{array}{l}\text { Crumbling } \\
\text { Easily }\end{array}$ \\
\hline Mucus & - & + & ++ \\
\hline \multicolumn{4}{|l|}{$4 \%$} \\
\hline Aroma & Normal & $\begin{array}{l}\text { Appear Acid } \\
\text { Smell }\end{array}$ & Rotten Odor \\
\hline Texture & Chewy & $\begin{array}{l}\text { Start to } \\
\text { Softened }\end{array}$ & $\begin{array}{l}\text { Crumbling } \\
\text { Easily }\end{array}$ \\
\hline Mucus & - & + & ++ \\
\hline
\end{tabular}

Description: (-) There was no mucus

(+) There was mucus (A little)

$(++)$ There was mucus (More)

\section{CONCLUSION}

The results of observing the effectiveness of sea cucumber extract on the growth of cancer cells and total meatball bacteria showed that the sea cucumber extract was able to inhibit the growth of cancer cells and was able to reduce the total bacteria in meatballs during processing. The effectiveness of sea cucumber 
extract is greatly influenced or stimulated by heating treatment. Based on the BSLT test, of the five types of sea cucumbers, two of them (Holothuria similis and Pearsonothuria graeffei) have high activity. Sea cucumber extract was also able to inhibit both bacterial and fungal growth on meatballs during storage at room temperature. The extraction method needs to be refined by avoiding the use of materials that are less environmentally friendly, especially such as chloroform, for example, considering the extract to be applied to functional foods. The content of organic acids or active compounds in sea cucumber extract needs to be isolated and purified. The content of active compounds in sea cucumber extract needs to be tested clinically on experimental animals for its effect on the growth of cancer cells.

\section{REFERENCE}

[1] Jemal A, Bray F, Center MM, Ferlay J, Ward E, Forman D (2011) Global Cancer Statistics. Ca Cancer J Clin. 61(2):69-90.

[2] Anonim. 2012. Satu Juta Jiwa Idap Kanker. Harian Kompas On line. 6 Februari 2012. Diakses tanggal 1 Maret 2012.

[3] Dini, D.R., Susiana, S., \& Suryanti, A., 2020. Eating habits of sea cucumber (Holothuria scabra) and sea cucumber sap (Holothuria vagabunda) in Karas waters, Batam City, Indonesia. Akuatikisle: Jurnal Akuakultur, Pesisir dan Pulau-Pulau Kecil 4(1): 13-19.

[4] Marni, R., Lestari, F., \& Susiana, S., 2020. Ecological potential and spread distribution pattern sea cucumber Holothuria scabra and Holothuria vagabunda at Tanjungkeramat waters in Pangkil Village Bintan Regency, Indonesia. Akuatikisle: Jurnal Akuakultur, Pesisir dan Pulau-Pulau Kecil 4(1): 7-11.
[5] Putram, N. M., Setyaningsih, I., and Tarman, K., 2017. Anticancer Activity from Active Fraction of Sea Cucumber. Jurnal Pengolahan Hasil Perikanan Indonesia, 20(1): 53.

[6] Bordbar S., F. Anwar, and Nazamid Saari. 2011. HighValue Components and Bioactives from Sea Cucumbers for Functional Foods-A Review. Mar. Drugs 2011, 9, 1761-1805; doi:10.3390/md9101761.

[7] Albuntana, A., Yasman, W. Wardhana. 2011. Uji Toksisitas Ekstrak Empat Jenis Teripang Suku Holothuridae Dari Pulau Penjaliran Timur Kepulauan Seribu Jakarta. Jurnal Ilmu dan Teknologi Kelautan Tropis Vol. 3 No.1. hal: 65 - 72 .

[8] Haris, N.A., R. Ningsih, A.A. Fitrianingsih, A. Hakim. 2013. Antibacterial Activity Test Sea Cucumber Extract (Holothuria scabra) Sidayu Coast Gresik Using Disk Diffusion Method. Alchemy: Journal of Chemistry, Vol. 2 No. 2. pp. 101-149.

[9] Sarah, Q.S., F.H. Anny, and M. Misbahuddin. 2017. Brine Shrimp Lethality Assay. Bangladesh J Pharmacol. 12: $186-189$.

[10] Anonimous, 2006. Pedoman Standar Prosedur Operasional Pengolahan Hasil Peternakan (Daging). Direktorat Pengolahan Hasil Pertanian, Direktorat Jenderal Pengolahan dan Pemasaran Hasil Pertanian, Departemen Pertanian, Jakarta.

[11] Badan Standardisasi Nasional. 1995. Standar Nasional Indonesia (SNI) Nomor: 01-3020-1995 Tentang Syarat Mutu Sosis Daging.

[12] Fardiaz, S. 1989. Mikrobiologi Pangan. Institut Pertanainan Bogor. Bogor

[13] Maturin, L.J. and J.T. Peeler, 2001. Aerobic Plate Count, In Bacteriological Analytical Manual, 8th ed. Revision A, AOAC International, Gaithersburg, USA, pp. 301-310

[14] Fajarningsih, N.D., H.I. Januar, M. Nursid, and T. Wikanta. 2006. Potensi antitumor ekstrak spons Crella papilata asal Taman Nasional Laut Kepulauan Seribu. Pascapanen dan Bioteknologi Kelautan dan Perikanan, $1(1): 35-41$. 